\title{
TUNTUTAN HAK-HAK SUAMI \\ PASCA PERCERAIAN: KAJIAN DI \\ MAHKAMAH SYARIAH KOTA BHARU, KELANTAN*
}

\author{
Husband's Claims Over Divorce Rights: \\ A Study at Kota Bharu Shariah Court, Kelantan
}

\author{
Nik Nur Athirah Nik Ibrahim \\ B.ShL Final Year Student, Department of Shariah and Law, \\ Academy of Islamic Studies, \\ University of Malaya, 50603 Kuala Lumpur. \\ nick_92@siswa.um.edu.my \\ Mohd Norhusairi Mat Hussin \\ Senior Lecturer, Department of Shariah and Law, \\ Academy of Islamic Studies, \\ University of Malaya, 50603 Kuala Lumpur. \\ husairi@um.edu.my
}

\begin{abstract}
As we all known, there are some legal rights that had been given and obtained by husband after divorce. The research is focused on the claim of these rights in Kota Bharu Shariah Court, Kelantan as enacted in Islamic Family Law Enactment No. 6 of Kelantan in 2002. Among the provided claims are matrimonial property (harta sepencarian) and child custody right (hadanah). It is focused on cases from 2013 until 2015 by referring to the statistics of claims initiated by husband and the rights that are successfully acquired. The outcomes show that only 6 over 40 cases of claim for matrimonial property right throughout the past three years were initiated by husband. Meanwhile, claims for child custody only 25 out of 72 cases were initiated by husband. The pattern of husband's
\end{abstract}

\footnotetext{
* Artikel ini merupakan Kertas Projek yang mendapat tempat pertama dalam pertandingan Kertas Projek Jabatan.

* Data-data dalam artikel ini diambil daripada Projek FP030-2016 Universiti Malaya 
claims over divorce rights each year are inconsistent and without positive rise compared to the claims initiated by wife.

Keywords: Harta Sepencarian, Matrimonial Property, divorce, Shariah Courts

\section{PENGENALAN}

Perkahwinan merupakan suatu Sunnah yang telah ditetapkan oleh Allah SWT bagi sesiapa yang berhasrat untuk melangsungkannya. Walau bagaimanapun, tidak semua ikatan perkahwinan yang dibina akan berkekalan. Ikatan ini akan terpisah apabila berlaku pergolakan dan sudah tiada harapan kepada jalan perdamaian. Ini kerana, panduan awal Islam kepada pasangan yang bertikai menyuruh untuk mengambil jalan berdamai dan mencari kesefahaman (Muhammad Abdul Rauf, 1994: 79). Ia boleh dilakukan dengan melantik individu yang dipercayai sebagai pendamai antara suami dan isteri. Setelah melalui cara perdamaian ini, namun tetap gagal mencapai jalan penyelesaian, maka hukum Syarak membenarkan perceraian walaupun ianya adalah sesuatu yang tidak digalakkan oleh Islam. Perkara ini dapat dilihat dari sabda Rasulullah SAW:

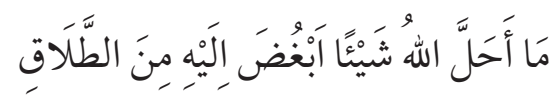

"Tiada sesuatu yang dihalalkan oleh Allah tetapi dibencinya lebih daripada perceraian..."

Walaupun perceraian adalah sesuatu yang dibenci, namun agama Islam mengambil jalan wașațiyah iaitu membenarkan perceraian tetapi perlu melihat kepada sebab-sebab yang munasabah dalam usaha untuk menjaga kemaslahatan dan menolak kemudaratan suami dan isteri. Sehubungan itu, rentetan daripada perceraian yang berlaku, maka terdapatnya beberapa hak yang berbangkit antara suami dan isteri mengikut hukum Syarak dan Enakmen Undang-Undang Keluarga Islam No. 6 Negeri Kelantan Tahun 2002 yang diperuntukkan kepada pasangan yang bercerai termasuk pihak suami. Perkara ini dapat dibuktikan melalui hak-hak yang telah disyariatkan kepada wanita adalah lebih banyak berbanding kaum lelaki. Namun, dalam hak-hak yang diberikan kepada wanita, terdapatnya beberapa hak bersama yang boleh dituntut pihak suami atau isteri iaitu haḍ̄nah dan harta sepencarian di mana ianya bukanlah satu hak yang mutlak dan eksklusif kepada wanita sahaja. Oleh itu, penelitian dan analisis adalah lebih memfokuskan kepada sudut pandang senario dan pelaksanaan tuntutan hak selepas perceraian oleh pihak suami di Mahkamah Syariah Kota Bharu di samping merujuk peruntukan Enakmen Undang-Undang Keluarga Islam No. 6 Negeri Kelantan Tahun 2002. 


\section{TUNTUTAN HAK-HAK SUAMI SELEPAS PERCERAIAN}

Menurut hukum Syarak dan Enakmen Undang-Undang Keluarga Islam No. 6 Negeri Kelantan Tahun 2002 diperuntukkan dua kategori hak-hak suami yang boleh dituntut apabila berlakunya perceraian iaitu:

\section{Hak Had̄ānah}

Haḍ̄nah merupakan hak bagi seorang anak yang masih kecil. Ia bukanlah hak ibu bapa sebaliknya menjadi tanggungjawab ibu bapa terhadap anakanak mereka yang masih lagi memerlukan perlindungan. Jika berlakunya pengabaian terhadap hak hadānah yang diberikan, ibu bapa tersebut telah melakukan suatu penganiayaan terhadap anak-anak (Ibn Qudāmah, 1983: 296). Ini bermakna, kedua-dua ibu bapa perlu memastikan penjagaan dan kepentingan anak-anak mereka adalah terpelihara meskipun mereka telah bercerai. Memang tidak dapat dinafikan bahawa hak penjagaan anak adalah lebih utama dan berhak kepada seorang ibu berbanding bapa. Perkara ini diperuntukkan di bawah Seksyen 82(1) Enakmen Keluarga Islam No. 6 Negeri Kelantan Tahun 2002 yang memperuntukkan bahawa ibu adalah orang yang paling berhak untuk menjaga anak kecilnya selagi ibu tersebut masih dalam perkahwinan dan selepas perkahwinannya dibubarkan. ${ }^{2}$

Sungguhpun begitu, hak penjagaan anak-anak kepada ibu sematamata bukanlah sesuatu perkara yang mutlak dan ianya merupakan sesuatu yang fleksible bergantung kepada keadaan pihak tersebut. Hal ini bukanlah bermaksud untuk menafikan sama sekali hak bapa atas kemampuan dan keupayaannya untuk memberikan kasih sayang dan menjaga emosi serta kebajikannya. Kehilangan hak penjagaan dalam kalangan ibu bukanlah sesuatu yang mustahil. Perkara ini telah diperuntukkan dalam undang-undang di bawah bahagian bagaimana keadaan yang dikatakan akan menyebabkan hilangnya hak jagaan sebagaimana yang diperuntukkan di bawah Seksyen 84 Enakmen Undang-Undang Keluarga Islam No. 6 Negeri Kelantan Tahun 2002. Oleh yang demikian, jika seseorang perempuan itu telah hilang kelayakan sebagai penjaga kanak-kanak tersebut. Maka, kelayakan ini akan berpindah kepada pihak lain sebagaimana yang diperuntukkan di bawah Seksyen 82(2) Enakmen yang sama.

Setelah itu, sesuatu perintah jagaan adalah tertakluk kepada apa-apa syarat yang difikirkan oleh mahkamah patut diberikan dan tertakluk kepada syarat-

2 Seksyen 82(1) Enakmen Undang-Undang Keluarga Islam No. 6 Negeri Kelantan Tahun 2002. 
syarat yang dipakai dari masa ke semasa di bawah Seksyen 88(2) Enakmen yang sama. Mahkamah dibenarkan dengan budi bicara yang dimiliki untuk memutuskan apa-apa perintah berkenaan penjagaan anak-anak yang difikirkan perlu dengan mengambil kira aspek kepentingan dan kebajikan anakanak tersebut. Dalam syarat ini juga dinyatakan bahawa mahkamah boleh memberikan hak lawatan atau sebagainya kepada ibu atau bapa yang tidak mendapatkan hak jagaan anak-anak dalam usaha untuk menjaga kebajikan dan pembesaran anak-anak dengan baik.

Dalam menilai pelaksanaan tuntutan hadānah oleh pihak suami, terdapat beberapa contoh kes yang tidak dilaporkan dan telah diputuskan oleh Mahkamah Tinggi Syariah Kota Bharu yang memberikan hak jagaan kepada pihak suami iaitu dalam kes Zainab bt Sulaiman lwn. Muhammad bin Hussain. ${ }^{3}$ Plaintif merupakan bekas isteri kepada Defendan. Manakala, Defendan merupakan bekas suami Plaintif. Mereka telah dikurniakan tujuh orang anak namun Plaintif hanya menuntut hak jagaan ke atas tiga orang anaknya yang berumur 9 tahun, 8 tahun dan 6 tahun. Perkara ini bermula apabila Defendan telah mengambil anak-anaknya di sekolah tanpa pengetahuan Plaintif.

Selain itu, Plaintif juga merasa sedih apabila Defendan telah tidak membenarkan anak-anak berjumpa dengan Plaintif dan memohon perintah hak jagaan kekal anak-anak tersebut kepadanya selaku ibu kandung dan memerintahkan hak lawatan dan bermesra dengan anak Defendan pada bilabila masa yang sesuai. Walaupun begitu, Defendan mengemukakan penyata pembelaan di mana Defendan menegaskan bahawa anak-anaknya telah cerdik dan mampu untuk membuat pilihan sendiri sama ada untuk tinggal bersama Plaintif atau Defendan.

Tambahan, Defendan bekerja sendiri dan ruang masa bersama anak-anak lebih banyak. Selain itu, Defendan juga menjelaskan bahawa Plaintif ketika ini sedang menumpang tinggal di rumah adiknya yang telah berkeluarga dan perkara ini amat tidak sesuai untuk penjagaan anak sedangkan anak-anak telah mempunyai tempat tinggal yang selesa. Di samping itu, Defendan juga menyatakan bahawa Plaintif bekerja di Hospital Universiti Sains Malaysia (HUSM) dan hampir setiap hari iaitu bermula pada jam 7.00 pagi dan pulang pada waktu senja. Keadaan-keadaan ini menunjukkan bahawa Plaintif tidak dapat memberikan perhatian kepada anak-anak sewajarnya.

Pada 13 Januari 2015, mahkamah telah mengeluarkan perintah hak jagaan anak-anak yang tersebut berdasarkan kepada keputusan pilihan anak-

$3 \quad$ Zainab bt Sulaiman lwn. Muhammad bin Hussain, Kes Mal No: 03100-028-04582014. 
anak yang terlibat. Oleh itu, mahkamah perintahkan ketiga-tiga anak yang dinyatakan diletakkan di bawah jagaan Defendan sebagai bapa kandung. Sementara itu, Plaintif sebagai ibu kandung diberi hak untuk melawat anakanak dan membawa anak-anak balik tanpa dihalang pada bila-bila masa yang sesuai dan munasabah.

\section{Hak Harta Sepencarian}

Istilah harta sepencarian adalah berasal daripada usaha "sama-sama sepencari" yang digunakan bagi pasangan suami isteri yang sama-sama bekerja membersihkan ladang dan menjadi kelaziman masyarakat Melayu dan peribumi di nusantara (Suwaid Tapah, 2007: 56). Pensyariatan berhubung harta sepencarian tidak dinyatakan secara jelas sama ada di dalam al-Quran ataupun Sunnah. Namun, ulama dalam mempersepakati perkara ini telah berhujah menggunakan pendekatan "urf dan ianya bertepatan dengan kaedah perundangan (qawā 'id fiqhiyyah) yang berbunyi "al- 'adah al-muhakkamah" yang bermaksud bahawa sesuatu yang diterima mengikut adat adalah sama kedudukannya mengikut syarak (Ibn Nujaym, 1968: 92).

Dalam konteks pembahagian harta sepencarian, takat sumbangan yang telah diberikan oleh pasangan suami dan isteri dalam usaha untuk mengumpul dan mengembangkan harta yang diperolehi sepanjang tempoh perkahwinan adalah diambil kira (Zaini Nasohah, 2002: 81). Harta sepencarian di negerinegeri lain ditafsirkan dalam Enakmen Undang-Undang Keluarga Islam di negeri-negeri. Namun, perkara ini berlainan di negeri Kelantan yang mana tafsiran kepada harta dan sepencarian ini perlu dirujuk di bawah Seksyen 2 Enakmen Pentadbiran Mahkamah Syariah Negeri Kelantan 1982. ${ }^{4}$ Menurut Enakmen Pentadbiran Mahkamah Syariah 1982, harta sepencarian adalah harta sama ada harta alih ataupun tak alih yang diperolehi oleh suami dan isteri melalui usaha modal bersama mereka semasa tempoh perkahwinan. Sungguhpun begitu, konsep dan amalan pembahagian harta ini adalah hampir sama antara sesebuah negeri yang lain. Peruntukan ada memberi penekanan tentang usaha atau modal yang disumbangkan oleh suami atau isteri dalam tempoh perkahwinan. Setelah itu, rujukan pembahagian kadar adalah dibuat mengikut pertimbangan mengikut hukum syarak (Suwaid Tapah, 2007: 63) dalam memastikan keadilan bahagian yang diperolehi dipersetujui oleh pihakpihak.

4 Seksyen 2 Enakmen Undang-Undang Keluarga Islam No. 6 Negeri Kelantan Tahun 2002. 
Di bawah Seksyen 122(1) menerangkan bahawa tuntutan harta sepencarian hanya boleh difailkan di mana pihak-pihak tersebut bercerai. Misalnya, jika perintah perceraian yang berlaku di antara suami dan isteri tersebut di Mahkamah Rendah Syariah Kota Bharu, maka mana-mana pihak yang ingin menuntut harta sepencarian perlu memulakan tuntutan di mahkamah yang sama sebagaimana perintah perceraian dikeluarkan.

Dalam menilai tuntutan hak harta sepencarian yang dituntut oleh pihak suami, dapat diteliti berdasarkan contoh-contoh kes yang tidak dilaporkan yang telah diputuskan oleh Mahkamah Tinggi Syariah Kota Bharu dalam kes Muhammad Asri bin Mohamed lwn. Adilah binti Haji Azman, ${ }^{5}$ yang mana memberikan keputusan kadar $1 / 2$ bahagian antara suami (Plaintif) dan isteri (Defendan). Plaintif dan Defendan telah memperolehi harta tak alih iaitu sebuah rumah teres satu tingkat yang dibina di atas tanah Lot 2211, GM 1850, Mukim Perok, Jajahan Tumpat, Kelantan. Rumah tersebut telah didaftarkan atas nama Defendan, namun Plaintif yang telah membeli hartanah tersebut dengan harga RM 28,290.00 dan telah melakukan renovasi secara berperingkat dengan jumlah keseluruhan lebih kurang RM 60,000.00 tanpa melibatkan apaapa sumbangan daripada Defendan.

Tindakan Plaintif mendaftarkan atas nama Defendan adalah kerana pada ketika itu Plaintif mempunyai masalah kewangan daripada institusi kewangan dan menyebabkan kewangan Plaintif kurang stabil. Rentetan daripada perceraian yang berlaku, Plaintif terpaksa keluar daripada hartanah tersebut walaupun ianya merupakan hakmilik Plaintif sepenuhnya. Defendan sedar dan tahu bahawa hartanah tersebut adalah di bawah pemilikan Plaintif namun masih berkeras untuk tidak mahu keluar daripada hartanah tersebut malahan telah mendiami hartanah itu bersama anak dan suaminya yang baru. Manakala, Plaintif pula terpaksa menyewa rumah lain dengan kadar sewa bulanan sebanyak RM 600.00 sebulan.

Justeru itu, melalui kaedah persetujuan bersama keputusan telah dikeluarkan oleh Mahkamah Tinggi Syariah dimana hartanah tersebut dibahagikan kadar pembahagian kepada Plaintif sebanyak $1 / 2$ bahagian dan Defendan $1 / 2$ bahagian. Selain itu, perintah turut dikeluarkan sekiranya Defendan ingin menjual hartanah tersebut, keutamaan hendaklah diberikan kepada Plaintif berdasarkan harga nilai pasaran semasa dan jika Plaintif menolak tawaran pembelian itu, maka Defendan boleh menjualnya kepada sesiapa sahaja. Melalui kes ini dapat dirumuskan bahawa tuntutan harta sepencarian adalah hak kedua-dua

5 Muhammad Asri bin Mohamed lwn. Adilah binti Haji Azman, Kes Mal No: 03100017-0549-2014. 
pihak dan pihak suami yang merasakan tertindas dengan hak yang dimilikinya dibenarkan untuk memulakan tuntutan terhadap hak harta sepencarian.

\section{ANALISIS}

Sebagaimana yang diketahui, tiada pasangan yang mahukan perkahwinan yang dibina berakhir dengan perceraian. Namun, terkadang ia tetap berlaku dalam usaha untuk menjamin kemaslahatan dan menolak kemudaratan pihak yang menanggung derita sama ada isteri atau suami. Secara umumnya, jumlah perceraian dalam masyarakat di negeri Kelantan dari tahun 2013 sehingga tahun 2015 yang telah didaftarkan di Mahkamah Rendah Syariah Kota Bharu adalah seperti jadual di bawah:

Jadual 1: Jumlah Perceraian Yang Didaftarkan di Mahkamah Rendah Syariah, Kota Bharu dari Tahun 2013-2015

\begin{tabular}{|c|c|c|c|c|}
\hline Tahun & $\begin{array}{c}\text { Tuntutan } \\
\text { Cerai }\end{array}$ & Cerai Taklik & $\begin{array}{c}\text { Tuntutan } \\
\text { Fasakh }\end{array}$ & $\begin{array}{c}\text { Jumlah } \\
\text { Keseluruhan }\end{array}$ \\
\hline $\mathbf{2 0 1 3}$ & 1002 & 180 & 21 & 1203 \\
\hline $\mathbf{2 0 1 4}$ & 655 & 138 & 22 & 815 \\
\hline $\mathbf{2 0 1 5}$ & 467 & 120 & 12 & 599 \\
\hline
\end{tabular}

Sumber: Unit Rekod Mahkamah Rendah Syariah Kota Bharu, Kelantan. ${ }^{6}$

Berdasarkan kepada jadual di atas, bentuk-bentuk pembubaran perkahwinan yang biasa berlaku adalah tuntutan cerai, cerai taklik dan juga tuntutan fasakh. Manakala, khulu' atau tebus talak amat kurang berlaku Seterusnya, didapati dalam tempoh tiga tahun ini, jumlah perceraian keseluruhan yang dicatatkan menunjukkan kadar penurunan yang begitu memberangsangkan dari tahun ke tahun. Kenyataan ini secara tidak langsung, telah menunjukkan perubahan dan kesedaran yang positif dalam kalangan masyarakat berbanding tahun-tahun sebelum ini.

Bertitik tolak daripada jumlah perceraian ini, secara langsungnya akan timbul tuntutan berbangkit berkenaan hak-hak suami dan isteri selepas perceraian. Pihak suami kebiasaannya hanya akan memulakan tuntutan hak terhadap harta sepencarian dan juga hak penjagaan anak yang mana ianya berbeza dengan pihak isteri. Dalam menimbangtara tuntutan hak harta sepencarian pihakpihak, Mahkamah akan mengambil kira elemen sumbangan pihak-pihak iaitu

6 Fadzlina Mamat @ Mohd Nor (Penolong Pegawai Syariah, Mahkamah Rendah Syariah Kota Bharu, Kelantan), dalam temu bual beliau bersama penulis pada 13 April 2016. 
sama ada terdapatnya sumbangan secara langsung atau sumbangan tidak langsung. Ini dapat dilihat kepada statistik jumlah tuntutan harta sepencarian yang didaftarkan di Mahkamah Tinggi Syariah, Kota Bharu iaitu:

Jadual 2: Statistik Kes Tuntutan Harta Sepencarian di Mahkamah Tinggi Syariah, Kota Bharu Bagi Tahun 2013-2015

\begin{tabular}{|l|c|c|c|c|}
\hline Perkara/Tahun & $\mathbf{2 0 1 3}$ & $\mathbf{2 0 1 4}$ & $\mathbf{2 0 1 5}$ & $\begin{array}{c}\text { Jumlah } \\
\text { Keseluruhan Kes }\end{array}$ \\
\hline Harta Sepencarian & 13 & 15 & 12 & $\mathbf{4 0}$ \\
\hline
\end{tabular}

Sumber: Unit Rekod Mahkamah Tinggi Syariah, Kota Bharu. ${ }^{7}$

Berdasarkan kepada jadual di atas, jelas menunjukkan bahawa jumlah tuntutan harta sepencarian yang didaftarkan di Mahkamah Tinggi Syariah Kota Bharu yang dituntut oleh kedua-dua pihak iaitu bekas suami dan juga bekas isteri adalah konsisten dan peningkatannya agak mendatar. Namun begitu, sepanjang tempoh kajian yang dilakukan terdapat sebanyak 4 kes yang dibatalkan iaitu 2 kes pada tahun 2014 manakala 1 kes bagi tahun 2013 dan tahun 2015. Antara perkara yang menyebabkan kes-kes ini dibatalkan oleh mahkamah adalah kerana pihak yang menuntut telah menarik balik kes dan kegagalan pihak yang menuntut hadir ke mahkamah untuk memberikan keterangan. 40 kes tuntutan harta sepencarian di atas adalah termasuk tuntutan yang dibuat oleh kedua-dua pihak di mana jumlah khusus tuntutan yang dimulakan oleh pihak suami adalah seperti berikut:

Jadual 3: Statistik Kes Harta Sepencarian Yang Dituntut Oleh Suami Bagi Tahun 2013-2015

\begin{tabular}{|l|c|c|c|}
\hline \multicolumn{1}{|c|}{ Perkara/Tahun } & $\mathbf{2 0 1 3}$ & $\mathbf{2 0 1 4}$ & $\mathbf{2 0 1 5}$ \\
\hline $\begin{array}{l}\text { Tuntutan Harta Sepencarian oleh } \\
\text { Suami }\end{array}$ & 2 orang & 1 orang & 3 orang \\
\hline
\end{tabular}

Sumber: Analisis Fail Kes.

Jumlah di atas menunjukkan bahawa, daripada 40 kes yang didaftarkan untuk tempoh tiga tahun hanya seramai 6 orang suami sahaja yang memulakan tuntutan ini di mahkamah selepas perceraian dan jumlah tuntutan yang tertinggi pernah dicatatkan iaitu seramai 3 orang pada tahun 2015. Secara tidak langsung, senario yang ditunjukkan ini menjelaskan bahawa tuntutan yang dimulakan oleh golongan suami adalah kurang berbanding tuntutan yang dimulakan oleh golongan isteri sedangkan ianya adalah merupakan

$7 \quad$ Norhasney Ridhwan Hassan (Ketua Pendaftar, Mahkamah Tinggi Syariah Kota Bharu, Kelantan), dalam temu bual beliau bersama penulis pada 13 April 2016. 
hak bersama yang diperuntukkan dalam Enakmen Undang-Undang Keluarga Islam No. 6 Negeri Kelantan Tahun 2002.

Setelah itu, melihat pula kepada kadar pembahagian harta sepencarian yang telah diputuskan oleh Mahkamah terhadap pihak suami iaitu dari tahun 2013 hingga 2015 adalah sebagaimana berikut:

Jadual 4: Kadar Pembahagian Kes Harta Sepencarian Yang Diperolehi Suami dari Tahun 2013-2015

\begin{tabular}{|c|c|c|c|c|}
\hline \multirow{2}{*}{ Tahun } & \multicolumn{3}{|c|}{ Kadar Harta Sepencarian Yang Diperolehi } & \multirow{2}{*}{ Jumlah } \\
\cline { 2 - 4 } & Kadar 1/3 & Kadar 2/3 & Kadar 1/2 & \\
\hline $\mathbf{2 0 1 3}$ & 0 & 6 & 6 & $\mathbf{1 2}$ \\
\hline $\mathbf{2 0 1 4}$ & 1 & 5 & 7 & $\mathbf{1 3}$ \\
\hline $\mathbf{2 0 1 5}$ & 0 & 4 & 7 & $\mathbf{1 1}$ \\
\hline
\end{tabular}

Sumber: Unit Rekod Mahkamah Tinggi Syariah, Kota Bharu.

Jadual di atas menunjukkan kadar pembahagian harta sepencarian yang diperolehi suami terhadap tuntutan yang dilakukan sama ada oleh pihak suami atau isteri. Oleh kerana harta sepencarian ini adalah hak tuntutan bersama, maka kedua-dua pihak sama ada suami atau isteri akan memperolehi kadar pembahagian harta yang sewajarnya setelah dinilai oleh mahkamah terhadap unsur sumbangan langsung atau tidak langsung pihak-pihak. Oleh hal demikian, jelas ditunjukkan bahawa majoriti golongan suami dari tahun 2013 sehingga 2015 mendapat kadar pembahagian harta sepencarian dalam kadar 2/3 dan $1 / 2$. Hal ini kerana, hakim mendapati bahawa golongan suami memberikan sumbangan yang lebih dan sumbangan yang dibuat dalam memperoleh hartaharta semasa tempoh perkahwinan manakala, pihak isteri pula lebih banyak kepada sumbangan secara tidak langsung di mana mereka mendapat kadar bahagian sebanyak 1/3 sahaja.

Kebiasaannya, perkara berkaitan pembahagian harta selepas perceraian iaitu harta sepencarian ini kerap kali isteri sahaja yang menuntutnya di mahkamah. Adapun sebenarnya golongan suami juga adalah berhak untuk membuat tuntutan ke atas harta sepencarian yang diusahakan sepanjang tempoh perkahwinan terutamanya jika harta-harta tersebut telah didaftarkan atas nama isteri sedangkan pemilikan penuh harta-harta tersebut adalah hak mutlak suami. Isu ini telah pun dibangkitkan dalam kes yang dibahaskan 
sebelum ini ${ }^{8}$ yang mana pihak suami terpaksa untuk mendaftarkan hartanah yang dibeli olehnya di atas nama isteri disebabkan dirinya mempunyai rekod kewangan yang kurang stabil dan baik. Setelah perceraian, si isteri telah enggan untuk mengosongkan hartanah tersebut dan dia telah tinggal di situ bersama suami barunya. Sementara, bekas suami ini terpaksa untuk menyewa di rumah yang lain.

Di samping itu, tuntutan harta sepencarian oleh pihak suami ini juga patut dilakukan apabila terdapat keadaan pihak suami yang kurang arif dalam mengendalikan dan menguruskan sesuatu harta yang diperolehi semasa tempoh perkahwinan. Maka, golongan suami ini akan menyerahkan tugasan pengurusan harta tersebut kepada pihak isteri sehingga tidak mengetahui jumlah sebenar harta tersebut. Dalam pada itu, berhubung tuntutan hak penjagaan anak oleh pihak suami di Mahkamah Tinggi Syariah Kota Bharu menggambarkan senario yang sama seperti dalam tuntutan harta sepencarian di mana pihak isteri adalah golongan yang lebih mendominasi dalam membuat tuntutan hak jagaan anak ini. Kenyataan ini dapat dilihat berdasarkan kepada jadual di bawah iaitu:

Jadual 5: Statistik Kes Haḍānah Yang Didaftarkan Di Mahkamah Tinggi

Syariah, Kota Bharu dari Tahun 2013-2015

\begin{tabular}{|c|c|c|c|c|}
\hline Kes/Tahun & $\mathbf{2 0 1 3}$ & $\mathbf{2 0 1 4}$ & $\mathbf{2 0 1 5}$ & Jumlah Keseluruhan Kes \\
\hline Tuntutan Hạ̣̄anah & 28 & 21 & 23 & 72 \\
\hline
\end{tabular}

Sumber: Unit Rekod Mahkamah Tinggi Syariah, Kota Bharu.

Berdasarkan kepada jumlah tuntutan haḍanah di atas, menunjukkan jumlah keseluruhan kes tuntutan yang dimulakan oleh kedua-dua pihak selepas perceraian ialah sebanyak 72 kes. Di mana berlaku sedikit pengurangan tuntutan pada tahun 2014 dan tahun 2015 manakala, pada tahun 2013 adalah jumlah tuntutan terbanyak yang dicatatkan.

Jadual 6: Statistik Kes Haḍānah Yang Dituntut Oleh Suami di Mahkamah Tinggi Syariah, Kota Bharu Bagi Tahun 2013-2015

\begin{tabular}{|c|c|c|c|}
\hline Perkara/Tahun & $\mathbf{2 0 1 3}$ & $\mathbf{2 0 1 4}$ & $\mathbf{2 0 1 5}$ \\
\hline Tuntutan Had̄ānah oleh Suami & 9 orang & 10 orang & 6 orang \\
\hline
\end{tabular}

Sumber: Analisis Fail Kes.

Jelas didapati berdasarkan Jadual 6 di atas, bahawa jumlah tuntutan haḍ̄anah yang paling tinggi yang dibuat oleh pihak suami adalah pada tahun 2014 iaitu seramai 10 orang manakala, jumlah yang paling rendah adalah pada

8 Muhammad Asri bin Mohamed lwn. Adilah binti Haji Azman, Kes Mal No: 03100017-0549-2014. 
tahun 2015 iaitu seramai 6 orang sahaja. Dengan itu, berdasarkan daripada Jadual 6 di atas didapati bahawa hanya sejumlah 25 kes daripada 72 kes yang dimulakan oleh pihak suami. Oleh yang demikian, jumlah selebihnya iaitu seramai 16 orang pada tahun 2013, 10 orang pada tahun 2014 dan 16 orang pada tahun 2015 yang menuntutnya adalah dari pihak isteri mahupun ahli keluarga. Kemudian, melihat pula kepada hak yang berjaya diperolehi oleh pihak suami sebagai individu yang mendapat hak jagaan kekal anak-anak dalam usaha untuk mendapatkan jagaan anak-anak.

Jadual 7: Statistik Bilangan Suami Yang Mendapat Hak Jagaan Kekal Anak di Mahkamah Tinggi Syariah, Kota Bharu Bagi Tahun 2013-2015

\begin{tabular}{|c|c|c|c|}
\hline Perkara/Tahun & $\mathbf{2 0 1 3}$ & $\mathbf{2 0 1 4}$ & $\mathbf{2 0 1 5}$ \\
\hline Hak Jagaan Kekal Anak & 3 orang & 2 orang & 4 orang \\
\hline
\end{tabular}

Sumber: Analisis Fail Kes.

Keputusan hak jagaan kekal anak di atas, bukan sahaja tuntutan yang dimulakan oleh pihak suami, malahan terdapat juga tuntutan yang dimulakan oleh pihak isteri yang mana ianya berdasarkan kepada pengamatan dan penilaian Mahkamah bahawa pihak isteri adalah tidak berkelayakan dalam mendapatkan hak jagaan anak disebabkan faktor-faktor yang tertentu.

Sebetulnya pihak suami juga berhak untuk membuat tuntutan hak jagaan ini terutamanya jika syarat-syarat yang dinyatakan tidak dipenuhi oleh ibu kepada anak-anak tersebut seperti contoh perempuan terbabit telah berkahwin dengan lelaki lain yang tiada pertalian darah dengan anak-anak oleh itu, pihak suami berhak untuk menuntut agar anak tersebut tinggal bersamanya.

Kebanyakan ibu yang mendapat hak hadānah disebut sebagai hadīnah manakala bapa atau penjaga lelaki yang tidak mendapat hak hadānah dipanggil sebagai walī kerana dia masih bertanggungjawab terhadap penjagaan diri walaupun dia tidak tinggal bersama anak-anak. Berdasarkan kepada penelitian terhadap kes-kes yang telah dibahaskan sebelum ini, terdapat hak sampingan lain yang diperintahkan oleh mahkamah kepada pihak yang tidak mendapat hak jagaan anak. Antaranya seperti hak jagaan dan lawatan yang diberikan pada bila-bila masa yang difikirkan sesuai dan munasabah. Ini menunjukkan bahawa kedua-dua pihak sama ada suami atau isteri tetap perlu memainkan peranan sebagai ibu atau bapa walaupun perceraian telah berlaku antara mereka. Disebabkan itulah, mana-mana pihak yang mendapat hak jagaan kekal sama ada dalam tempoh hadānah atau selepasnya adalah tidak berhak untuk menghalang akses pihak yang satu lagi. 
Di samping itu, terdapat bentuk penjagaan yang lain yang turut dipegang oleh bapa atau pihak lelaki, iaitu hak penjagaan ke atas harta kanak-kanak yang memerlukan kepada penjagaan harta oleh bapa sebagai wakil yang utama kepada harta tersebut. Walaupun ibu atau pihak isteri mendapat hak haḍanah anak-anak, namun dia tidak berhak terhadap perwalian ke atas diri dan harta anak-anak kerana pihak isteri bukanlah penjaga hakiki yang sah di sisi undang-undang. Perkara ini adalah selaras dengan apa yang diperuntukkan di bawah Seksyen 89(1) Enakmen Undang-Undang Keluarga Islam No. 6 Negeri Kelantan Tahun $2002^{9}$ yang menyebut bahawa:

"Sungguh pun hak terhadap hadhanah atau penjagaan anak mungkin terletak pada seseorang lain, bapa adalah penjaga hakiki yang pertama dan utama bagi diri dan harta anaknya yang belum dewasa, dan apabila bapa telah mati, maka hak di sisi undang-undang bagi menjaga anaknya itu adalah turun kepada salah seorang yang berikut mengikut susunan keutamaan yang berikut, iaitu:

(a) Datuk lelaki di sebelah bapa

(b) Wasi yang dilantik menurut wasiat bapa

(c) Wasi kepada wasi bapa

(d) Wasi datuk lelaki di sebelah bapa

(e) Wasi kepada wasi datuk di sebelah bapa"

\section{METOD PENDEKATAN MAHKAMAH DALAM PENYELESAIAN TUNTUTAN HAK SELEPAS PERCERAIAN}

Pendekatan yang diambil oleh Mahkamah Tinggi Syariah Kota Bharu dalam memutuskan pertikaian yang melibatkan harta sepencarian dan haḍ̄nah adalah dengan mengaplikasikan prosedur șulh atau persetujuan bersama pihak-pihak. Perkara ini dapat diperhatikan kepada kes-kes yang dibahaskan oleh penulis dalam perbincangan sebelum ini. Tindakan yang diambil oleh mahkamah adalah bertepatan dengan Arahan Amalan No.1 Tahun $2010^{10}$ yang dikeluarkan oleh Jabatan Kehakiman Syariah Malaysia (JKSM) yang menyatakan bahawa:

"Kes-kes yang disenaraikan adalah perlu dirujuk kepada Majlis Sulh semasa peringkat pendaftaran kes dan antaranya

\footnotetext{
9 Seksyen 89(1) Enakmen Undang-Undang Keluarga Islam No. 6 Negeri Kelantan Tahun 2002.

10 Arahan Amalan No.1 Tahun 2010, berkuatkuasa pada 30 Julai 2010.
} 


\section{termasuklah kes tuntutan harta sepencarian dan tuntutan hadhanah..."}

Di samping itu, ianya juga bertepatan dengan syarat-syarat berkaitan dengan hak yang dipertikaikan yang dianjurkan untuk diadakan șulh iaitu seperti bahawa perkara itu merupakan harta yang boleh dinilai atau sesuatu yang bermanfaat dan bahawa ianya adalah hak seseorang yang harus ditukar ganti sekalipun bukan berbentuk harta. Pendekatan Mahkamah dengan mengadakan sulh antara pihak-pihak yang bertikai terutamanya dalam tuntutan harta sepencarian dan had̄anah ini adalah sesuatu pendekatan secara praktikal yang lebih bersifat budi bicara. Hal ini kerana, persetujuan bersama yang dicapai oleh pihak-pihak adalah terhasil daripada perasaan redha dan tolak ansur yang mana terkadang keadilan sebegini tidak dapat diperolehi melalui perbicaraan dan hukuman di Mahkamah.

\section{KESIMPULAN}

Secara ringkasnya, didapati bahawa tuntutan hak suami selepas perceraian sepertimana yang telah diperuntukkan di dalam Enakmen Undang-Undang Keluarga Islam No. 6 Negeri Kelantan Tahun 2002 adalah menepati kehendak hukum Syarak dan telah dilaksanakan oleh badan kehakiman di Mahkamah Tinggi Syariah Kota Bharu walaupun jumlah tuntutannya masih berada dalam tahap yang sederhana. Namun begitu, pendedahan dan kesedaran perlu dimaksimumkan dalam memberi pengetahuan dan peluang kepada pihak suami yang mana mungkin tidak tahu mengenai hak yang diberikan ini. Di samping itu, galakan tuntutan hak suami selepas perceraian ini adalah bukanlah bermaksud untuk mengurangkan hak yang diperolehi oleh pihak isteri, namun ianya adalah bertujuan untuk memberikan hak kepada yang berhak berdasarkan kepada budi bicara Mahkamah Yang Mulia yang mana kedua-dua hak yang diperuntukkan itu adalah merupakan hak bersama yang diperolehi suami dan isteri sepanjang tempoh perkahwinan berlangsung.

\section{RUJUKAN}

'Alī, W.B. (1999). al-Tafriq bī al-Aīb bayn al-Zawjayn. Jeddah: Maktabāh Kunūz al-Ma'rifah.

Abdullah, R. (2007). "Hak Nafkah dan Hadhanah," dalam Undang-Undang Islam di Malaysia Prinsip dan Amalan, ed. Ahmad Hidayat Buang. Kuala Lumpur: Universiti Malaya, 79-97.

Abdullah, W. N. (2014). al-Tafsir al-Maudhu'iy. Kuala Lumpur: Dewan Bahasa dan Pustaka. 
Ahmad Mudjab Mahalli, A. R. (2004). Hadis-Hadis Muttafaq 'Alaih: Bahagian Munakahat dan Muamalat. Jakarta: Kencana.

Ahmad, S. A. (2000). Kefahaman Wanita Terhadap Hak-Hak Selepas Perceraian: Kajian di Jitra Kedah. Kuala Lumpur: Universiti Malaya.

al-Bahutī, M.B. (1983). Kisyāf al-Qinā, vol. 4. Beirūt: 'Alam al-Kutub.

Bakar, M. Z. (2012). Permasalahan Hak Pasangan dalam Undang-Undang Keluarga Islam di Malaysia. Kedah: Universiti Utara Malaysia.

al-Bardis̄̄, M.Z. (n.d.). al-Aḥwāl al-Shakhșīyyah. Qāhirah: Maktabāh Yūsuf. al-Bāyānī, M.N.D. (1991). Da if Sunan Abī Dawūd. Maktābah al-Islāmiyah.

Bhattacherjee, A. (2012). Social Science Research: Principle, Methods and Practices. Florida: University of Florida Scholar Commons.

al-Faqih, Y. (1989). al-Aḥwāl al-Syakhșīyyah. Beirūt: Dār al-Adhwa.

Hamid, M.M. (1957). al-Ahwal al-Shakșīyyah fi al-Syari'ah al-Islamīyyah. Mesir: Maktābah al-Tijāriyyah al-Kubrā.

Hamzah, N. (2008). Batas-Batas Persamaan Hak Antara Lelaki dan Wanita: Analisis dari Perspektif Islam. Kuala Lumpur: Universiti Malaya.

Hasbullah, A. (1968). al-Fiqh bayna al-Zawjaynī wama Yata 'allaq biha 'Iddah wa Nasaban. Qāhirah: Dār al-Hudūd al-Jadīd.

al-Husaynī, T.A.D. (n.d.). Kifāyah al-Akhyār, vol. 2. t.t.p.: Dār al-Ma'rifah.

Ibn Nujaym, Z.A. (1968). al-Ashbah wa al-Nadhā'ir. Mesir: t.p.

Ibn Qudāmah, M. (1983). al-Mughnī li Ibn Qudāmah, vol. 9. Beirūt: Dār alKitāb al-'Arabī.

Ibrahim, A. (2013). Undang-Undang Keluarga Islam di Malaysia. Lexis Nexis.

Ibrahim, A.M. (1997). Pentadbiran Undang-Undang Keluarga Islam di Malaysia. Kuala Lumpur: Institut Kefahaman Islam Malaysia.

Idris, A.G. (1994). Hukum-Hukum Perkahwinan \& Kekeluargaan dalam Islam: Pandangan daripada Pelbagai Mazhab. Kuala Lumpur: Dinie Publisher.

al-Jazirīi, A.R. (1998). al-Fiqh al-Madhāhib al-Arba 'ah, vol. 4. Beirūt: Dār Ihya' al-Turāth al-'Arabī.

al-Kahlanī, M.B. (1379). Sūbl al-Salām, vol. 3. Mesir: t.p.

Kamaruddin, Z. (2005). Divorce Laws in Malaysia (Civil and Shariah) Malayan Law Journal. Singapore, Malaysia. Hongkong: Lexis Nexis.

al-Khatīb, S.M.S. (1996). al-Iqnā fì Hāl Alfāz Abī Shujā, vol. 2. T.t.p: Dār alKhayr. 
Mahmood Zuhdi, H.A. (1989). Undang-Undang Keluarga Islam: Konsep dan Perlaksanaanya di Malaysia. Kuala Lumpur: Karya Azabie.

Mahmood, M.S. (1984). Undang-Undang Keluarga dalam Islam. Kelantan: Jabatan Hal Ehwal Agama Islam Kelantan.

Muhamad, M.F. (2003). Undang-Undang Keluarga Islam dalam Empat Mazhab: Pembubaran Keluarga, vol. 2. Serdang: Universiti Putra Malaysia.

al-Mutallaq, A.B. (2008). Fiqh Sunnah: al-Aḥwāl al-Syakhṣīyyah, vol. 3. t.t.p.: Dār Kanuz Eshbelia.

Nasohah, Z. (2002). Perceraian: Hak Wanita Islam. Kuala Lumpur: Utusan Publications and Distributions Sdn. Bhd.

al-Nawawī, A.Z. (t.t.). Minhaj al-Tālibìn. t.t.p.: al-Taba'ah al-Misrīyyah.

Othman, A. (2000). "Hak Wanita dalam Undang-Undang Keluarga Islam," dalam Undang-Undang Keluarga Islam dan Wanita di Negara-Negara Asean. Kuala Lumpur: Institut Kefahaman Islam Malaysia, 189-226.

Qaddura, Z. (1971). Islam and Family Planning: Women's Right in Islam, vol. 1. Beirut: t.p.

Rauf, M.A. (1994). The Islamic Family: A General View. Kuala Lumpur: Dewan Bahasa dan Pustaka.

Sābiq, A.S. (1885). Fiqh al-Sunnah, vol. 7. Beirūt: Dār al-Kitāb al-'Arabī.

al-Saīs, A. (1969). Muqāranah al-Madhāhib fì al-Fiqh. Qahirah: Maktābah al-Kullīyyah al-Azharīyyah.

Shalabī, M.M. (1977). Aḥkām al-Usrah fì al-Islām. Beirūt: Dār al-Nahụah al'Arabīyyah.

Shaltut, M. (n.d.). al-Islām: Aqīdah wa al-Syarī'ah.

al-Sharbīn̄̄, A.S.M.K. (1958). Mughnī al-Muhtājj. Mesir: Maktābah Mustafa Muhammad.

Sheikh Kamil Muhammad, M. (1996). al-Jami' fì Fiqh al-Nisā'. Jakarta: Pustaka al-Kauthar.

Stuart Macdonald, N.H. (t.t.). Research Methods Handbook. Manchester: Express Network.

Syakir, A.M. (1932). Niz̄ām al-Ṭalāq fì al-Islām. t.t.p.: al-Maktabah alAzhariyyah.

Tapah, S. (2000). "Kedudukan Hak Isteri dari Perspektif Hukum Syarak dan Undang-Undang Keluarga Islam di Malaysia," Jurnal Syariah, 57-68. 
Tapah, S. (2007). "Harta Perkahwinan (Harta Sepencarian)," dalam UndangUndang Islam di Malaysia Prinsip dan Amalan, ed. Ahmad Hidayat Buang. Kuala Lumpur: Universiti Malaya.

Tapah, S. (2007). "Prosedur Perceraian," Undang-Undang Islam di Malaysia Prinsip dan Amalan, ed. Ahmad Hidayat Buang. Kuala Lumpur: Universiti Malaya, 31-54.

al-Tha'thawī, A.S.A. (2003). Tanbīh al-Ibrār bī Ahkām al-Khulū wa al-Talāq wā al-Zihār. Dār al-Kutub al-'Ilmiyyah.

Yaacob, A. M. (2006). "Harta Sepencarian," Manual Undang-Undang Keluarga Islam. Kuala Lumpur: Institut Kefahaman Islam Malaysia.

Yusof, N. (2004). "State Intervention in Regulating Divorce: A Case Study in the Shariah Court of Federal Territory of Kuala Lumpur," in Islamic Family Law: New Challenges in the 21st Century, vol. 2. Gombak: International Islamic University Malaysia, 181-193.

Zaydān, K. (2001). al-Waj̄̄z fì Syarah al-Qawā 'id al-Fiqhīyyah fì al-Syarī'ah al-Islāmiyyah. Muasasah al-Risālah.

Zin, N. M. (2006). "Pembubaran Perkahwinan dan Permasalahan Berbangkit," Manual Undang-Undang Keluarga Islam. Kuala Lumpur: Institut Kefahaman Islam Malaysia, 161-182.

al-Zuhaylī, W. (1985). al-Fiqh al-Islamī wa Adillātuhu: al-Aḥwāl alSyakhșīyyah, vol. 7. Suriah: Dār al-Fikr.

\section{Senarai Statut}

Arahan Amalan Jabatan Kehakiman Syariah Malaysia (JKSM), No. 1 Tahun 2010

Enakmen Undang-Undang Keluarga Islam No. 6 Negeri Kelantan Tahun 2002.

\section{Senarai Temu bual}

Fadzlina Mamat@Mohd Nor (Penolong Pegawai Syariah, Mahkamah Rendah Syariah Kota Bharu, Kelantan), dalam temu bual beliau bersama penulis pada 13 April 2016.

Norhasney Ridhwan Hassan (Ketua Pendaftar, Mahkamah Tinggi Syariah Kota Bharu, Kelantan), dalam temu bual beliau bersama penulis pada 13 April 2016.

Samsudin Ismail (Penolong Pegawai Syariah (Kanan), Mahkamah Tinggi Syariah Kota Bharu, Kelantan), dalam temu bual beliau bersama penulis, pada 13 April 2016. 